\title{
Saturn mission feels Congress' frustration
}

Washington. A congressional bid to cancel the planned international Cassini mission to Saturn, as well as to eliminate three of the US National Aeronautics and Space Administration (NASA)'s 11 centres, has touched off a storm of protest both in Europe and in the US Congress.

The reaction was so strong that the plan may well be dropped when the full committee meets. But the space agency is not yet home and dry, as Republican budget-cutters in Congress continue to search for major programmes to eliminate.

The bid came from the House appropriations subcommittee that funds not only NASA but also the Environmental Protection Agency (EPA), the National Science Foundation and a miscellany of other government departments. The subcommittee voted on 10 July to cut NASA's 1996 budget request by 5 per cent, to $\$ 13.54$ billion.

The space shuttle, the space station, and the Earth Observing System (EOS) would all be funded in full. But the subcommittee proposed cancelling both the 1997 Cassini mission to orbit Saturn, a mission being planned jointly with the European Space Agency (ESA) and the Italian space agency (ASI), and the proposed Gravity Probe-B relativity experiment.

It also recommended delaying two infrared astronomy projects, SOFIA and SIRTF, and - most radical of all - closing down the Goddard Space Flight Center in Maryland, the Marshall Space Flight Center in Alabama and the Langley Research Cen- ter in Virginia. Transferring their missions to other NASA centres would save some $\$ 130$ million a year, the subcommittee suggested.

Howls of protest were immediately heard from congressional representatives of states where the threatened centres are located,

\section{IMAGE UNAVAILABLE FOR COPYRIGHT REASONS}

\section{Cassini: cancellation proposals upset ESA.}

who called in Daniel Goldin, the administrator of NASA, for strategy meetings. Senator Barbara Mikulski (Democrat, Maryland), for example, expressed her "deep dismay and disappointment" in a letter to the subcommittee chair, Jerry Lewis (Republican, California).

Her colleague Richard Shelby (Republican, Alabama) described the vote as "ludicrous, poor policy, and complete nonsense". He added: "I will do everything in my power to see that this does not happen and that

\section{ESA warns of blow to cooperation}

Paris. The European Space Agency (ESA) last week warned that the proposal by a budget subcommittee of the US Congress to cancel the joint US-European Cassini-Huygens mission (see above) risks damaging future cooperation in space.

In particular, officials said it could have a major impact on Europe's planned participation in the international space station. If the subcommittee's recommendation is adopted by the full Congress, it would represent a "major crisis" for ESA, warns Roger Bonnet, head of science at the agency.

Bonnet adds that the committee's position "shows a complete lack of concern for proper financial management, and a failure to properly evaluate the consequences on international politics".

ESA is particularly upset at the prospect of the mission being cancelled because it has already spent $\$ 220$ million of the $\$ 300$ million direct costs of the Huygen's probe, as well as another $\$ 200$ million in general costs associated with the mission.

"We thought that the project was safe, as it is almost completed", says Bonnet. He adds that the agency is scheduled to supply the satellite to the US National Aeronautics and Space Administration next year.

Bonnet also predicts that such a situation will also make Europe even more reluctant to cooperate with the United States in future space missions. ESA officials are already upset by US vacillation over participation in joint missions, for example over its withdrawal from the Ulysses missions to the Sun, and last year the agency decided to design all future missions so that their main scientific goals could be achieved even if partners withdrew (see Nature 368, 786; 1994)

Jean-Marie Luton, the director-general of ESA, has already written a letter of protest to the congressional subcommittee.

Declan Butler this ridiculous suggestion goes in its proper place - the trash." Both Mikulski and Shelby sit on the Senate appropriations panel that oversees NASA funding.

A game of bluff between Goldin and Lewis seems to have been partly to blame for the subcommittee's action. Lewis had asked Goldin several times to recommend cuts in the agency's Mission to Planet Earth (which includes EOS). But Goldin had refused, steadfastly standing by the Clinton administration's budget request. Lewis said before the subcommittee vote he was left with no choice but to propose his own cuts as a "warning shot" to the agency.

The subcommittee's recommendations are not being taken too seriously in Washington. One house aide called the proposal a "non-starter", adding that the decision was motivated more by politics than a desire to shape a meaningful NASA budget. (Much of the work from the Goddard, Marshall and Langley centres, for example, would be transferred to centres in California, Lewis's home state).

Space programme observers see little chance of Goddard, the agency's lead science centre, closing down, particularly with Mikulski defending it. As for Cassini, most of the spacecraft development money - $\$ 1.1$ billion out of a projected $\$ 1.4$ billion — has already been spent, and supporters say it would be foolish to kill the project now. Terminating Cassini would also have a chilling effect on delicate negotiations about Europe's participation in NASA's space station project (see box, left). That argument alone may ensure the project's survival.

But the vote still took NASA - and some congressional members - by surprise. It also provoked the House Science committee, chaired by Robert Walker (Republican, Pennsylvania), to speed up work on its own authorizing legislation for NASA's 1996 budget. This was partly, in Walker's words, to "offer some clear alternatives to the appropriators before [the NASA funding bill] goes to the House floor".

Walker's bill is expected to be completed this week, just as the whole appropriations committee considers the Lewis subcommittee's recommendation. The bill would then go to the full House late this week or next week. The Senate takes up NASA funding in August or September, and the agency's final budget is likely to be decided in a reconciliation process in late September.

The Walker committee is likely to recommend keeping Cassini on track. But it is also expected to propose deep cuts to EOS, and may recommend cancelling some or all of NASA's proposed new projects, including the New Millennium technology demonstration spacecraft and the low-budget Lunar Prospector mission to map the Moon.

Tony Reichhardt 